\title{
The ethics of genetic screening: the first report of the Nuffield Council on Bioethics: another personal view
}

\author{
David Shapiro Executive Secretary of the Nuffield Council on Bioethics
}

In the previous issue of the journal Dr Gillon opened up a debate about the role and work of the Nuffield Council through the critical comments he offered on the council's first report, Genetic Screening: Ethical Issues (1). He did so in a manner which was, to borrow his words, 'liberal, commonsensical and humane'. I am grateful for his personal invitation to respond as Executive Secretary of the council.

$\mathrm{He}$ also deserves the thanks of the council itself. The report was intended to provoke public discussion. As the chairman's preface made clear: 'The report could not hope to identify exhaustively, let alone answer, all the ethical questions which may confront individuals, families and professionals' (2). What the council had sought to do was to expose 'the complex range of ethical issues ... to wide professional and public debate'. Dr Gillon's editorial makes a welcome contribution to that debate; after an admirable introductory summary of the report's conclusions and recommendations, he sets out a challenge to what he describes as 'the relative lack of academic rigour of its argument and justification for its conclusions', and to what, in his view, is the Nuffield Council's failure to measure up to 'the Gold Standard of such reports provided by the US President's Commission on Bioethics' (1).

To consider first the specific example cited by $\mathrm{Dr}$ Gillon: the 'release of genetic information to potentially seriously affected family members. The council hardly acknowledges the existence of arguments in favour of maintaining absolute confidentiality ...' (3). But, as the report points out: 'the duty of confidentiality is not absolute' (4) whether under common law, under the Data Protection Act 1984, or under the General Medical Council's guidance to doctors. This follows a lengthy passage (5) that starts with an exposition of 'the importance of confidentiality'.

Dr Gillon goes on to say that the report presents no argument at all against making appropriate sharing with family members a condition of screening.

\section{Key words}

Genetic screening; ethics committees.
But is it appropriate or equitable to make such conditions binding on those being screened? The report (6) noted a study that underlines 'the importance of avoiding any coercion in genetic screening programmes'. The report emphasised (7) that 'what particularly marks out genetic screening are the potential implications for the family'. From that it follows (8) that 'the kinds of information and procedures that people need to help them decide whether or not to be screened for a genetic disorder' include 'information about the implications of screening positive (abnormal) for their future and existing children and for other family members'. But I readily accept that the family implications of genetic screening will require the further discussion recommended in the report (9). This needs to be done in the light not so much of argumentation as of accumulating practical experience gained in the increasing number of pilot screening programmes (10).

I am less disposed to accept what Dr Gillon indicates to be his view about the nature of the report that should come from such a body as the Nuffield Council on Bioethics. Should they be like the reports of the US President's Commission on Bioethics characterized as containing, beyond Genetic Screening: Ethical Issues, 'extensive, rigorous and sustained ethical, jurisprudential, sociological, religious and other argument, stemming from stated moral premises and taking into account strong counter arguments to their own positions' (3)?

The council's report was intended to address an audience that included, as well as the health professions involved in the delivery of genetic screening, both government and those industries that should be concerned. What was likely to be most effective both in attracting the attention and giving guidance to such an audience? There is a neat contemporary contrast. The American Institute of Medicine published Assessing Genetic Risks at roughly the same time. The Institute of Medicine's report is more than five times as long and costs more than four times as much. No doubt the Institute of Medicine's Assessing Genetic Risks has the references that may lighten the load of some members of the academic bioethics community: But the Nuffield Council on 
Bioethics was not established with the primary aim of serving that academic bioethics community.

In a sense the council may be parasitic upon academic bioethics: for we depend on the academic work done in that community. Our terms of reference, however, require the council:

1. to identify and define ethical questions raised by recent advances in biological and medical research in order to respond to, and to anticipate, public concern;

2. to make arrangements for examining and reporting on such questions with a view to promoting public understanding and discussion; this may lead, where needed, to the formulation of new guidelines by the appropriate regulatory or other body; and

3. in the light of the outcome of its work, to publish reports; and to make representations, as the council may judge appropriate.

The efficient discharge of those terms of reference requires a simpler and clearer presentation of the arguments than the more elaborate approach of $\mathrm{Dr}$ Gillon. His specification is much more suited to the academic writing in bioethics. This point is reinforced by the effects of the UK's membership of the European Union. Our national bioethics debates need to influence the debates being conducted both within the European Union and within the Council of Europe. The Council of Europe is about to publish its draft framework convention on bioethics. Within the European Commission the Group of Advisers on Ethical Implications of Biotechnology, under the chairmanship of Mme Noëlle Lenoir, is widening the range of topics on which it is prepared to pronounce. All this means that an effective contribution to European discussion needs to be in a form that is fairly readily accessible to policy-makers whose mother tongue is not English.

The Gold Standard, in Dr Gillon's estimation, is the reports of the US President's Commission for the Study of Ethical Problems in Medicine and Biomedical and Behavioral Research. There can be high costs to gold standards, but I shall dismiss the temptation to quote from Keynes's The Economic Consequences of $\mathrm{Mr}$ Churchill. The more serious point is that bioethics has moved on in the decade since the dissolution of the US President's Commission. Could any national bioethics body, however well staffed, now sensibly attempt to issue reports to $\mathrm{Dr}$ Gillon's specification? Why should such bodies replicate his work and that of his academic colleagues?

In any case that specification, as formulated by Dr Gillon, is open to question. What is meant by his phrase 'rigorous and sustained ethical ... argument, stemming from stated moral premises' (3)? Dr Gillon is a well known enthusiast for 'the Georgetown mantra'. He has recently published
Principles of Health Care Ethics which runs to 1,152 pages and costs $£ 125$. As Lady Warnock observed in reviewing it (11) such is the generality of the four principles of beneficence, non-maleficence, respect for autonomy, and justice that it is difficult to use them to solve ethical dilemmas. That is not to deny that they are pedagogically useful and offer practitioners profitable guidance. The problems come when these principles clash as, for example, in the treatment of genetic information relevant to other family members.

The Nuffield Council on Bioethics did look carefully at whether it could hope to agree on stated moral premises of general application from which it would be possible to formulate solutions to particular problems. Dr O'Neill's paper for the council has been published in the Bulletin of Medical Ethics (12). It noted the strengths and weaknesses in four main approaches to moral philosophy: utilitarianism, rights-based ethics, virtue ethics and dutybased ethics. The council concluded that it was unlikely to be able to proceed in the fashion recommended by Dr Gillon.

Finally, if more resources were made available for the council's work, how should they be applied? This journal circulates to academics, and many of its readers may be inclined to feel that the councif should attempt to follow the editor's prescriptions The council's terms of reference point it in different direction, towards the model set by the Danish Council of Ethics. The Danish council has set a very successful example in engaging the public in widespread discussion of ethical issues. The record can be read in its annual reports, which are published in English.

Even with its limited resources, the Nuffield Council on Bioethics aims to extend its work in promoting public discussion. A shorter version of Genetic Screening: Ethical Issues is being prepared for a wider audience. We have hopes that some of the women's organisations will promote wide discussion of the issues raised in our first report. For it is primarily women who will have to face these issues in the first instance, particularly so long as genetic screening is largely done at an antenatal stage.

This line of thought would seem to move the council's role and priorities still further from the of model of the US President's Commission $N$ commended by Dr Gillon. Should this be a cause for N concern? Not, I suggest, if the Nuffield Council on $\omega$ Bioethics's analyses of ethical issues are both sound and clear, and if the conclusions reached are not in any way deficient through a failure to draw upon the $\stackrel{\Phi}{\rightarrow}$ academic literature. The council will look forward to reactions from others to this debate which Dr Gillon has so helpfully opened.

David Shapiro is Executive Secretary of the Nuffield $\stackrel{\varpi}{\circ}$ Council on Bioethics. He was Reader in Government, Brunel University, 1972-1988. 


\section{References}

(1) Gillon R. Editorial: a personal view: Ethics of genetic screening: the first report of the Nuffield Council on Bioethics. Fournal of medical ethics 1994; 20: 67-68, 92.

(2) Nuffield Council on Bioethics. Genetic screening: ethical issues. London, 1993: II.

(3) See reference (1): 68 .

(4) See reference (2): 48: para 5.23.

(5) See reference (2): 44-48: paras 5.9 to 5.22 .

(6) See reference (2): 34: para 4.13.

(7) See reference (2): $31:$ para 4.7.

(8) See reference (2): 31: para 4.8 .
(9) See reference (2): 53: para 5.42.

(10) Livingstone J, Axton R A, Gilfillan A et al. Antenatal screening for cystic fibrosis: a trial of the couple model. British medical journal 1994; 308: 1451-1452; Raeburn S. Screening for carriers of cystic fibrosis. British medical journal 1994; 308: 1459-1462; Super M, Schwarz M, Malone G, Roberts T, Haworth A, Dermody G. Active cascade testing for carriers of cystic fibrosis gene. British medical journal 1994; 308: 1462-1468.

(11) Warnock M [book review]. Principles of health care ethics. British medical journal 1994; 308: 988-989.

(12) O'Neill O. Introducing ethics: some current positions. Bulletin of medical ethics 1991; 73: 18-21.

\section{Continued from page 132}

(5) Kennedy I, Grubb A, eds. Medical law: texts and materials. London: Butterworths, 1989: 1074, and more generally, 1066-1155.

(6) British Medical Association. Medical ethics today - its practice and philosophy. London: BMJ publishing group, 1993: 165, and more generally, 147-179.

(7) President's Commission for the study of ethical problems in medicine and biomedical and behavioural research. Deciding to forego life-sustaining treatment - ethical, medical and legal issues in treatment decisions. Washington, DC: US Government Printing Office, 1983: 90, and more generally, 43-90.

(8) Stanley J, ed. The Appleton international conference: developing guidelines for decisions to forego lifeprolonging medical treatment. Fournal of medical ethics (supp) 1992; 18: 1-24.

(9) Hastings Center. Guidelines on the termination of life-sustaining treatment and the care of the dying. Briarcliff Manor, NY: The Hastings Center, 1987: $60,16-34$.

(10) Lynn J. Introduction and overview. In: Lynn J, ed. By no extraordinary means - the choice to forgo lifesustaining food and water. Bloomington, Indianapolis: Indiana University Press, 1986: 4.

(11) Skegg P. Law, ethics and medicine - studies in medical law. Oxford: Clarendon Press, 1984: 143. 